\title{
Peningkatan Penguasaan Kosakata Bahasa Inggris pada Mahasiswa Prodi Bahasa Inggris melalui Metode Demonstrasi
}

\author{
Rina Puji Utami ${ }^{(1)}$ \\ ${ }^{1}$ Program Pendidikan Bahasa Inggris, STKIP PGRI Nganjuk \\ Email: ${ }^{1}$ rinapuji@ stkipnganjuk.ac.id
}

\begin{tabular}{l}
\hline Tersedia Online di \\
\hline http://www.jurnal.unublitar.ac.id/ \\
index.php/briliant
\end{tabular}

Sejarah Artikel

Diterima pada 28 April 2018

Disetuji pada 9 Agustus 2018

Dipublikasikan pada 13 Agustus

2018 Hal. 338-344

\begin{tabular}{l}
\hline Kata Kunci: \\
\hline metode demonstrasi, kosakata \\
\hline
\end{tabular}

DOI:

http://dx.doi.org/10.28926/briliant .$v 3 i 3.185$

\begin{abstract}
Abstrak: Penelitian ini bertujuan untuk mengetahui peningkatan prestasi kosakata mahasiswa dengan menggunakan metode demonstrasi. Dengan penggunaan metode ini diharapkan kelemahan kosa kata Bahasa Inggris dapat teratasi sehingga prestasi penguasaan kosa kata tersebut dapat meningkat. Metode demonstrasi pada penelitian ini menggunakan materi prosedur sesuai dengan tingkat pemahaman mahasiswa pada mata kuliah Vocabulary untuk mahasiswa semester empat, Program Pendidikan Bahasa Inggris STKIP PGRI Nganjuk. Jumlah total mahasiswa adalah 21 mahasiswa. Peningkatan prestasi kosa kata mahasiswa tersebut dapat diketahui dengan analisis pada penelitian ini menggunakan metode "t-test": to= (M_1-M_2)/SE_(M1-M2 ). Hasil analisis data komputasi, nilai "t" menunjukkan peningkatan hasil penguasaan kosakata mahasiswa dengan menggunakan metode demonstrasi yakni 4,91 dan tabel "t" tingkat signifikan adalah 5\%. Nilai kritik "t" dalam tingkat signifikan dari tabel 2,03 (> tt atau $4,91>2,03$,
\end{abstract}

Di era globalisasi ini, menguasai Bahasa Inggris bagi mahasiswa pada umumnya dan Program Pendidikan Bahasa Inggris pada khususnya bukan hanya merupakan mata kuliah tetapi telah menjadi suatu kebutuhan yang dapat digunakan untuk berinteraksi dan berkomunikasi dengan dunia internasional. Bahasa Inggris telah menjadi salah satu alat untuk kegiatan komunikasi dan interaksi di dunia internasional ini. Dalam kamus Oxford (1989: 700) dinyatakan bahwa : "bahasa adalah sistem pada suara, kata-kata, pola, dll yang digunakan oleh manusia untuk mengkomunikasikan pikiran dan perasaan". Berdasarkan pernyataan itu jelas bahwa bahasa adalah alat untuk mengungkapkan gagasan. Sebagai bahasa internasional dan sebagai sarana komunikasi di dunia dan memiliki peran yang sangat penting untuk berinteraksi dengan dunia internasional

Kemajuan teknologi dan era globalisasi memaksa manusia tidak hanya memiliki atau menguasai satu bahasa saja tetapi juga bahasa lainnya terutama Bahasa Inggris. Karena itu Bahasa Inggris sebagai salah satu bahasa asing yang diajarkan di sekolah Indonesia. Bahasa Inggris sebagai bahasa internasional memiliki peran penting untuk mengembangkan ilmu pengetahuan, misalnya di negara-negara berkembang seperti Indonesia. Di Indonesia, bahasa Inggris merupakan bahasa asing meskipun meskipun diajarkan mulai dari sekolah menengah hingga perguruan tinggi tetapi kenyataannya sebagian besar siswa/mahasiswa khususnya Jurusan Pendidikan Bahasa Inggris masih 
menunjukkan bahwa kosakata mereka masih lemah sehingga mengakibatkan lemah pula dalam penguasaan mata kuliah yang berkaitan dengan empat kompetensi Bahasa Inggris yakni mendengarkan, berbicara, membaca dan menulis. Maka dari itu penguasaan kosa kata sangat diperlukan untuk menguasai Bahasa Inggris dengan baik sehingga mahasiswa tersebut dapat menyesuaikan dengan dengan perkembangan ilmu pengetahuan dan teknologi modern agar menjadi produk pendidikan yang memiliki kualifikasi yang relevan dengan perkembangan internasional.

Bahasa Inggris di Indonesia diajarkan mulai pendidikan dasar atau menengah sampai perguruan tinggi.Sebagai Program pendidikan Bahasa Inggris mahasiswa sudah seharusnya mempunya bekal kosa kata untuk mengusai kompetensi yang berkaitan dengan Bahasa Inggris dengan baik. Dengan pengusaan Bahasa Inggris yang baik mereka akan mampu mnyelesaikan program pendidikannya dan dapat mengembangkan pengetahuan lain yang banyak referensinya menggunakan Bahasa Inggris. Karena itu dalam Kurikulum Program Pendidikan Bahasa Inggris Mahasiswa selain mendapat mata kuliah yang berkaitan dengan pendidikan dan ke empat kemampuan Bahasa Inggris mahasiswa juga dibekali mata kuliah Vocabulary (Kosa kata). Mata Kuliah diberikan pada semester empat.

Kosa-kata merupakan salah satu komponen yang memiliki peran penting dalam penguasaan Bahasa Inggris, sehingga tanpa penguasaan kosa kata yang cukup dapat menjadi kesulitan bagi mahasiswa untuk mengekspresikan opininya dan memahami pengetahuan dan materi dalam Bahasa Inggris.Banyak mahasiswa berpendapat bahwa penguasaan kosa kata mereka masih lemah dan tidak mudah karena selain pada pendidikan sebelumnya pembelajaran Bahasa Inggris kurang mendapatkan pemahaman khusus pada kosa kata tetapi juga karena penulisan kosa kata Bahasa Inggris berbeda dengan pengucapan dalam bentuk jenis kosa, kata asli dan bentukan serta fungsi katanya sehingga prestasi penguasaan kosa kata masih rendah dan tujuan pembelajaran masih belum berhasil walaupun dosen telah mencoba menggunakan beberapa cara seperti ceramah dan diskusi dalam kegiatan dalam pengajaran kosa kata yang merupakan bekal pengusaan keempat kemampuan Bahasa Inggris. Maka dari itu dosen pengampu mata kuliah vocabulary harus berinovasi dalam kegiatan pengajaran dengan metode yang cocok untuk mahasiswa selain metode ceramah dan diskusi tersebut untuk meningkatkan prestasi penguasaan kosa kata yang dicapai oleh mahasiswa.

Dalam penelitian ini penulis memilih materi prosedur karena pada zaman modern khususnya di bidang pendidikan sering kita temukan penggunaan instruksi bagaimana melakukan, membuat dan mengoperasikan sesuatu dalam bentuk tulisan atau ucapan langsung atau tidak langsung dalam Bahasa Inggris pada berbagai bidang atau tempat-tempat umum, sehingga perlu bagi pembaca untuk memahami instruksi tersebut dengan baik dan bermaksud untuk menghindari kesalahpahaman informasi.

Ada beberapa arti untuk kosakata. Dalam tulisan ini penulis menyajikan makna kosakata menurut kamus, yaitu: "jumlah kata yang (dengan peran untuk menggabungkannya) membentuk bahasa, berbagai kata yang diketahui atau digunakan oleh seseorang dalam profesi perdagangan, buku yang berisi daftar kata: daftar kata yang digunakan buku "AS Hornby (1988: 101). 
Kosakata adalah pengetahuan yang mempelajari tentang kata, bagian dari kata yang memberi petunjuk pada makna seluruh kata. Richard (2003: 255) menyatakan bahwa Kosakata adalah komponen inti dari kemampuan berbahasa dan menyediakan banyak dasar untuk seberapa baik pembelajar berbicara, dengarkan, baca, dan tulis. Lebih lanjut, Nation (1990) dan Laufer (1992) menemukan bahwa mengetahui minimal sekitar 3.000 kata diperlukan untuk pembacaan yang efektif di tingkat perguruan tinggi, sedangkan mengetahui 5000 kata menunjukkan kemungkinan keberhasilan akademis. Dari penjelasan tersebut menunjukkan bahwa penguasaan kosa kata merupakan komponen yang harus mahasiswa kuasai sedikitnya dalam jumlah minimal 3.000 sampai 5.000 kosa kata di tingkat perguruan tinggi terutama Program Pendidikan Bahasa Inggris.Dalam pengusaan kosa kata tersebut tentunya diperlukan strategi yang dalam penelitian ini yakni metode demonstrasi partisipasi untuk pembelajaran kosa kata yang efektif.

Kosakata penting dalam mempelajari keterampilan bahasa. Tanpa memiliki kosakata yang cukup seseorang tidak mungkin berbicara atau berkomunikasi dalam bahasa Inggris. Menurut Fisher dan Terry (1997: 83) pembelajar mendapatkan kosakata dari lingkungan. Lingkungan meluas dalam waktu termasuk buku, radio dan televisi. Kosakata berkembang melalui pengalaman satu asosiasi pengalaman dengan kata. Setiap kata pada dasarnya adalah sebuah konsep. Dengan memahami, konsep yang terkait dengan kata, pembelajar bahasa memahami arti kata.

Memahami kata-kata bahasa Inggris dengan lebih baik bukanlah hal yang mudah. Ini membutuhkan lebih banyak pengetahuan bahasa tentang bahasa Inggris itu sendiri. Dosen pengampu mata kuliah vocabulary menyadari bahwa ada aturan dan pola yang berbeda antara Bahasa Inggris dan bahasa Indonesia.

Sejalan dengan pendapat di atas, Kustaryo (1988: 16) mengatakan, "Para pembelajar menghadapi kesulitan ketika mempelajari kata-kata dari bahasa target, karena dua bahasa ini, Inggris dan Indonesia bukan cabang dari bahasa yang sama, mereka memiliki pola sintaksis yang berbeda".

Selanjutnya, Kustaryo (1988: 16) mengatakan bahwa kata-kata bahasa Inggris sangat kompleks dan kompleksitas ini membawa kesulitan bagi siswa yang mencoba mempelajarinya. Kesulitan datang dari kata-kata itu sendiri, yang biasanya disebut dan yang intrinsik.

Selain itu, masalah pembentukan kata-kata juga penting diperhatikan karena kata-kata bahasa Inggris dibuat melalui beberapa cara seperti dengan peracikan, pencampuran singkatan dan afiksasi. Penting juga untuk mengetahui jenis arti kata-kata bahasa Inggris untuk membantu memahami kosakata dengan lebih baik.

Seperti yang kita ketahui, dalam belajar Bahasa Inggris ada empat keterampilan bahasa yang harus dicapai oleh pembelajar, yaitu : mendengarkan, berbicara, membaca dan menulis. Semuanya sangat terkait dengan penguasaan kosa kata dalam mempelajari Bahasa Inggris sebagai bahasa asing. Keahlian kosakata akan memungkinkan pembaca untuk mendapatkan keterampilan membaca. Tanpa akuisisi kosakata, seseorang akan sulit mengembangkan kemampuannya dalam penguasaan bahasa. Dalam masalah ini, "Terlepas dari bahasa target spesifik dan kondisi instruksi, kosakata merupakan faktor penting dalam semua pengajaran bahasa" Edward David Allen (2001 : 91). 
Berdasarkan Haycraf, dalam Hatch and Brown (1995: 370) dalam Brian Firmanto (2004: 16), kosakata dapat diklasifikasikan dalam dua kelompok, kosa kata reseptif dan produktif. Kosa kata reseptif adalah kata-kata yang siswa kenali dan pahami ketika mereka muncul dalam konteks tetapi mereka tidak dapat memproduksinya dengan benar. Selain itu, kosakata produktif adalah kata-kata yang dimengerti dan dilafalkan dengan benar oleh mahasiswa dan digunakan secara konstruktif dalam berbicara dan menulis. Itu berarti, dalam kosa kata reseptif mahasiswa tahu makna kata-kata tetapi mereka tidak dapat mengucapkannya dengan baik

Dalam kaitannya dengan pembelajaran, Dra.Roestiyah (2001: 83) memberikan definisi tentang demonstrasi sebagai berikut : Demonstrasi adalah cara mengajar dimana seorang instruktur menunjukkan, memperlihatkan, suatu proses, sehingga seluruh pembelajar dalam kelas dapat melihat, mengamati, mendengar atau mungkin meraba-raba dan merasakan proses yang dipertunjukkan oleh instruktur tersebut

\section{METODE}

Penulis menggunakan pendekatan eksperimen, karena penelitian ingin menerapkan dan membuktikan metode akan berhasil. Dalam penelitian ini penulis juga ingin mencoba dan membuat eksperimen dalam penelitiannya tentang prestasi kosakata siswa melalui demonstrasi. Jadi jenis yang digunakan dalam penelitian ini adalah desain eksperimen. Desain eksperimental digunakan untuk membandingkan hasil prestasi kosakata siswa yang akan diamati sebelum dan sesudah menerapkan metode.

Untuk mengetahui peningkatan prestasi kosakata mahasiswa penulis menganalisis data statistik menggunakan teknik "T-test". Itu digunakan untuk mengetahui prestasi kosa kata mahasiswa dengan menerapkan metode demonstrasi sebelum dan sesudah implementasi diberikan.

Rumusnya sebagai berikut :

$$
\begin{aligned}
& \mathrm{t}_{\mathrm{o}} \quad=\frac{M_{1}-M_{2}}{\mathrm{SE}_{\mathrm{M} 1}-\mathrm{Mz}} \\
& \mathrm{M}_{\mathrm{x}} \text { atau } M_{1} \quad=\frac{\sum \mathrm{x}}{\mathrm{N}_{1}} \\
& \mathrm{SD}_{1} \quad=\sqrt{\frac{\sum X^{2}}{N_{1}}} \\
& \mathrm{SE}_{\mathrm{M} 1}=\frac{\mathrm{SD}_{1}}{\sqrt{N_{1}-1}} \\
& \mathrm{SE}_{\mathrm{M} 1-\mathrm{M} 2}=\sqrt{\mathrm{SE}_{\mathrm{M} 1^{2}}+\mathrm{SE}_{\mathrm{M} 2^{2}}} \\
& \begin{array}{ll}
\mathrm{M}_{\mathrm{y}} \text { atau } M_{2} & =\frac{\sum \mathrm{Y}}{\mathrm{N}_{2}} \\
\mathrm{SD}_{2} & =\sqrt{\frac{\sum Y^{2}}{N_{2}}}
\end{array} \\
& \mathrm{SE}_{\mathrm{M} 2} \quad=\frac{\mathrm{SD}_{2}}{\sqrt{N_{2}-1}} \\
& \text { Df } \quad=\left(N_{1}+0\right)-1
\end{aligned}
$$

Dimana :

$$
\begin{array}{ll}
\mathrm{t}_{\mathrm{o}} & =\text { t observasi } \\
\mathrm{M}_{\mathrm{x}}\left(\mathrm{M}_{1}\right) & =\text { Rata-rata variabel } 1 \\
\mathrm{M}_{\mathrm{y}}\left(\mathrm{M}_{2}\right) & =\text { Rata-rata variabel } 2 \\
\mathrm{SD} & =\text { Standar deviasi } \\
\mathrm{SE} & =\text { Standart error }
\end{array}
$$


Df $=$ Degrees of freedom

\section{HASIL}

Penulis mendeskripsikan hasil kerja mahasiswa berdasarkan prestasi penguasaan kosa kata dengan menggunakan metode demonstrasi. Seberapa jauh mahasiswa dapat menangkap makna dari tes penguasaan kosa kata yang diberikan sehingga dapat dilihat kemampuan mahasiswa dalam penguasaan kosakata yang telah diikuti dengan menggunakan metode demonstrasi. Para mahasiswa dapat menyatakan memahami jika mahasiswa dapat memilih dengan benar jenis kosa kata atau arti kosakata tersebut sesuai dengan konteksnya. Dalam hal ini penulis dapat mengevaluasi peningkatan kosa kata menggunakan materi prosedur melalui metode demonstrasi. Diskusi pencapaian kosakata mahasiswa sebelum melakukan eksperimen dengan menerapkan metode demonstrasi untuk semester empat mahasiswa Prodi Bahasa Inggris STKIP PGR Nganjuk pada tahun akademik 2016/2017.

Dari analisis data penulis menemukan bahwa: ada 2 siswa mendapat skor antara 85 - 90, 13 siswa mendapat skor antara 70 - 80, dan 7 siswa mendapat nilai antara 60 - 65. Menurut data di atas, masih banyak siswa yang masih memiliki skor yang cukup dan lemah dalam kosakata sebelum penelitian eksperimen.

Secara teoritis bagi dosen hasil penelitian sangat bermanfaat sebagai aspek pertimbangan mereka dalam melakukan proses belajar mengajar dan kosakata. Dalam hal ini, dosen dapat menemukan bahwa hasil dari pencapaian kosakata sebelum penelian eksperimen dalam pengajaran mata kuliah vocabulary dengan materi prosedur tidak maksimal. Untuk siswa hasilnya memberikan deskripsi sederhana bagi mereka untuk mengetahui metode yang cocok untuk belajar pembelajaran dan meningkatkan kosakata mereka. Secara praktis, penelitian ini diharapkan dapat menjadi solusi terbaik untuk menyelesaikan masalah tentang metode dalam mempelajari kosakata. Ini berarti dosen dan mahasiswa akan memiliki pertimbangan tentang cara terbaik untuk proses belajar dan pembelajaran kosa kata ini.

\section{PEMBAHASAN}

Pembahasan hasil kosa kata siswa tingkat lanjut setelah eksperimen menerapkan demonstrasi untuk semester keempat mahasiswa tingkat lanjut STKIP PGRI Nganjuk pada tahun akademik 2016/2017.

Prestasi penguasaan kosa kata mahasiswa setelah penelitian eksperimen dengan menerapkan metode demonstrasi dalam proses belajar mengajar materi prosedur mendapat data sebagai berikut: 19 mahasiswa mendapat skor antara 70 80, 1 mahasiswa mendapat skor antara 85 - 90, dan 1 mahasiswa mendapat skor 95 poin.

Dengan hasil di atas menunjukkan bahwa dosen pengampu mata kuliah vocabulary telah memilih cara terbaik dalam proses belajar mengajar dan belajar kosakata dalam perkuliahan mata kuliah vocabulary. Dosen pengampu mata kuliah vocabulay dapat meningkatkan prestasi kosakata mahasiswa melalui metode demonstrasi dalam mengajar dan belajar materi prosedur. Jadi, metode ini dapat digunakan dalam mempelajari kosakata untuk memotivasi mahasiswa dan meningkatkan nilai mereka dalam mata kuliah vocabulay dan selanjutnya secara mandiri menerapkan dalam ke empat ketrampilan Bahasa Inggris. 
Pembahasan tentang perbedaan yang signifikan antara prestasi penguasaan kosakata sebelum dan sesudah penelitian eksperimen dengan menerapkan metode demonstrasi untuk mahasiswa mahasiswa Program Pendidikan Bahasa Inggris STKIP PGRI Nganjuk pada tahun akademik 2016/2017.

Berdasarkan hasil, skor rata-rata prestasi belajar mahasiswa sebelum penelitian eksperimen dengan menggunakan metode demonstrasi adalah 71,81 dan skor mereka setelah percobaan menerapkan demonstrasi adalah 79,86. Itu berarti satu lebih baik dari yang lain. Dari analisis di atas terdapat hasil yang signifikan antara prestasi kosakata maha sebelum dan sesudah percobaan penerapan metode demonstrasi untuk mahasiswa Program studi Bahasa Inggris STKIP PGRI Nganjuk pada tahun akademik 2016/2017.

Jika kita melihat bahwa skor 4,91 lebih berarti bahwa signifikansi $5 \%=$ $2,03$ dan signifikansi $1 \%=2,72$. Ini dapat ditulis $2,03<4,91\rangle 2,72$. Berdasarkan analisis di atas, terdapat perbedaan yang signifikan antara prestasi kosakata mahasiswa sebelum eksperimen (X) dan setelah (Y) menerapkan metode demonstrasi dengan materi prosedur pengajaran untuk mahasiswa semester empat STKIP PGRI Nganjuk pada tahun akademik 2016/2017. Artinya, ada perbedaan signifikan antara hasil pre test dan post test.

\section{KESIMPULAN}

Berdasarkan hasil analisis data dan sesuai dengan masalah, tujuan dan hipotesis penulis memiliki kesimpulan bahwa terdapat perbedaan yang signifikan antara prestasi belajar siswa sebelum dan sesudah diberikan demonstrasi dalam mengajar dan belajar topik teks prosedur untuk siswa kelas empat STKIP PGRI Nganjuk pada tahun akademik 2016/2017, nilai rata-rata prestasi belajar siswa sebelum metode demonstrasi yang diberikan adalah 71,81 dan skor mereka setelah diberikan metode demonstrasi adalah 79,86. Ini berarti bahwa setelah metode demonstrasi diterapkan, skor peningkatan kosakata siswa meningkat.

\section{SARAN}

Dari hasil penelitian yang dilakukan bahwa metode demonstrasi efektif untuk meningkatkan kosakata pada mahasiswa bahsa inggris maka metode ini dapat digunakan dan dikembangkan lagi oleh tenaga pengajar/dosen sehingga pembelajaran dapat berjalan sesuai dengan tujuan. Selain itu tenaga pengajar juga harus bisa menjadi fasilitator dan motivator yang baik bagi anak didik sehingga mereka dapat lebih kreatif dan berprestasi.

\section{DAFTAR RUJUKAN}

Brown, H Douglas. 1994. Teaching by Principles and Interactive Approach to Language Pedagogy. New Jersey : Prentice - Hall. Inc.

Hatch, E \& Brown. C. 1995. Vocabulary, Semantics and Language Education. New York : Cambridge University Press.

Hornby, A.S. 1986. Oxford Advantage's Dictionary of Current English. Oxford University Press, New York.

Hornby, A.S. 1989. Oxford Advantage's Learner Dictionary of Current English. Oxford University Press, London.

Kustaryo, S. 1988, Reading Techniques for College Students. Jakarta: Dekdikbut LPTK. 
Roestiyah N.K (2001). Strategi Belajar Mengajar. Salah Satu Unsur Pelaksanaan Strategi Belajar dan Teknis Pengajian. Jakarta : PT. Rineka Cipta. 